\title{
Early Seedling Growth as a Tool to Assess the Tolerance of Urochloa brizantha Cultivars to Free Aluminium
}

\author{
Claudia Jaqueline Tome Yamamoto ${ }^{1}$, Mariana Bassanezi Gasparim ${ }^{1}$, Nelson Barbosa Machado-Neto ${ }^{1}$ \\ $\&$ Ceci Castilho Custodio ${ }^{1}$ \\ ${ }^{1}$ Agronomy College, Universidade do Oeste Paulista, Campus II, Presidente Prudente, SP, Brazil \\ Correspondence: Ceci Castilho Custodio, Agronomy College, Universidade do Oeste Paulista (UNOESTE), \\ Campus II, Bloco B2, Rodovia Raposo Tavares km 572, Limoeiro, Presidente Prudente, SP 19067175, Brazil. \\ E-mail: ceci@unoeste.br
}

$\begin{array}{lc}\text { Received: April 12, } 2018 & \text { Accepted: May 14, } 2018 \quad \text { Online Published: June 15, } 2018 \\ \text { doi:10.5539/jas.v10n7p67 } & \text { URL: https://doi.org/10.5539/jas.v10n7p67 }\end{array}$

The research was financed by CAPES and CNPq.

\begin{abstract}
In this study we aimed to evaluate changes in germination, early seedling growth, and some biochemical parameters in Urochloa brizantha cultivars (Basilisk, Marandu, MG4, MG5, BRS Piatã, and Xaraés) subjected to five levels of free aluminium toxicity $\left(0,1,2,4\right.$, and $\left.8 \mathrm{mmol}_{\mathrm{c}} \mathrm{dm}^{3} \mathrm{Al}^{3+}\right)$, and to verify the selection efficiency of aluminium tolerant cultivars. In the germination assay, lots were submitted to germination under simulated stress conditions in the laboratory, to quantify root protrusion, number of normal seedlings, shoot and root length, and dry mass. In the early seedling growth assay, evaluations were done on the seventh day after subjecting seedlings to aluminium stress conditions. Relative growth rate of length, and dry mass of shoots and roots, superoxide dismutase activity (SOD), and concentrations of proline, total antioxidants (TEAC), and malondialdehyde (MDA) were evaluated. During the seedling study period, up to 14 days after sowing, the most tolerant cultivar maintained root growth in aluminium stress conditions, while the most susceptible cultivar reduced root growth, and developed proportionally more shoots, as shoot growth depends on seed reserves. The germination assay indicated interference of the initial seed quality with increasing $\mathrm{Al}^{3+}$ concentrations. The results indicate that the early seedling growth assay, which excluded germination effects, and used the measurement of root attributes, is appropriate for the discrimination of $\mathrm{Al}^{3+}$ tolerant genotypes. The Marandu cultivar was the most similar to the $\mathrm{Al}^{3+}$ tolerance standard Basilisk cultivar.
\end{abstract}

Keywords: pastures, Brachiaria, aluminum, stress, seedling growth assay

\section{Introduction}

Dairy milk and beef production in Brazil take place in large pasture areas (167 million ha, Beefpoint, 2016), and a great portion of these areas consists of cultivated grasses ( $70 \%$ or 115 million ha, EMBRAPA, 2014). Meat exports from Brazil are worth around US\$ 5.9 billion (Beefpoint, 2016), and Brazil is the largest exporter and the second largest producer of beef in the world (USDA, 2018), with beef exports only surpassed by exports of sugarcane, soybeans, and cereals (IBGE, 2006). Increasing fodder productivity and consequently the capacity of stocking animals could increase the capacity of carbon sequestration by up to one $\mathrm{Mg} \mathrm{C}^{-1} \mathrm{year}^{-1}$, and decrease the deforestation pressure (Oliveira Silva et al., 2016), freeing up areas for cropping.

Urochloa (syn. Brachiaria) plants are perennials, have a good response to fertilizers, and stay green during moderate periods of drought, especially when they are grown under liming, mineral feeding, and irrigation as a normal crop. These plants are able to adapt to different soils, and are resistant to some pests such as the spittlebug. They further have a high dry mass production and high palatability, resulting in elevated ingestion by livestock (Karia et al., 2006). Urochloa plants can be used for direct grazing, silage, haymaking, and have recently been used as a mulch in direct sowing systems in tropical regions (Costa et al., 2014; Flávio Neto et al., 2015), and as part of crop-livestock-forestry systems (Balbino et al., 2012). This increase in the use of forage seed has helped in the development of the Brazilian seed industry, and Brazil changed from being a seed importer in the early 1970's to becoming the largest producer, consumer, and exporter of tropical forage seeds in 
the world, exporting over 100,000 $\mathrm{Mg}$ year $^{-1}$ of seeds to over 40 countries (Ferreira, 2016).

Aluminium in acidic soils at $\mathrm{pH}<5.5$, is usually present in concentrations ranging from 3.3 to $117 \mathrm{mmol}_{\mathrm{c}} \mathrm{dm}^{-3}$ (Machado 1997), and aluminium concentrations can reach up to $83 \mathrm{mmol}_{\mathrm{c}} \mathrm{dm}^{-3}$ in Brazilian soils (Cunha et al., 2015). As such, aluminium plays an important role in agriculture and livestock farming, directly affecting the physiological and metabolic processes of most cultivated species (Martins et al., 2010). This may be reflected in low yields of crops, which is generally associated with low calcium availability $\left(<4 \mathrm{mmol}_{\mathrm{c}} \mathrm{dm}^{-3}\right)$ and high aluminium concentrations $\left(>5 \mathrm{mmol}_{\mathrm{c}} \mathrm{dm}^{-3}\right.$ ) (Raij et al., 1997). The solution for crop production in soils with high aluminium concentrations is a combination of management practices, liming associated with nutrient correction, and using cultivars developed for these conditions (Sano et al., 2008). In the case of pastures, which usually occupy marginal areas, these problems are even more serious, and among the recommended Urochloa brizantha, the Basilisk cultivar is reported to be the most resistant to acidic soils and to those with high aluminium concentrations (Rao et al., 2006).

Tolerance/resistance to aluminium may be achieved by either exudation of organic ions (Delhaize et al., 1993a, b; Silva et al., 2013; Ma et al., 2014; Roselló et al., 2015; Ahmed et al., 2016; Chen \& Liao 2016) or by excluding the aluminium from the roots in the outer layers of the exodermis (Arroyave et al., 2011, 2013). Aluminium causes oxidative stress in plants, leading some species to increase the activities of antioxidant enzymes (Giannakoula et al., 2010; Silva, 2012). It seems that increasing activities of antioxidant enzymes, such as superoxide dismutase, peroxidase, or catalase, occurs quickly in susceptible lines, and was noted just a few hours after stress induction, and tolerance may be partially triggered by the increased activity of the antioxidant system (Giannakoula et al., 2010).

Considering the need for greater pasture productivity, and the need to avoid using new areas and maintain sustainability in the agricultural sector, it is important to continue using acidic soils with high concentrations of aluminium and the associated tolerant cultivars (Martins, 2010). This is especially true in a culture that can be maintained for over 15 years without renewal, under appropriate conditions (Sano et al., 2008). Thus, it is necessary to select materials, mainly in the more susceptible stage, that can progress from seed germination to early seedling growth, a fundamental phase for the effective establishment of any crop, and a stage that may reflect the behaviour of the mature plant.

Selection can be done in many ways, and the hydroponic method with air supply has been used for testing many cultures (Giannakoula et al., 2010; Arroyave et al., 2011, 2013, 2017; Matins et al., 2011; Miguel et al., 2011; Roselló et al., 2015). Selection has also been done under field conditions (Mutimura \& Everson 2012), and using a semi-hydroponic method (Colombo et al., 2016), but these techniques may be expensive, difficult, and time consuming. Other alternatives may include early evaluation using germination tests or early seedling growth under controlled conditions (Custódio et al., 2002; Machado Neto et al., 2004; Custódio et al., 2009; Echer et al., 2010; Rosado et al., 2012), and the evaluation of some effective parameters in the cultivars.

The aim of this study was to evaluate changes in the germination, early seedling growth, and some biochemical parameters in cultivars of Urochloa brizantha (Marandu, BRS Piatã, MG4, MG5, Xaraés, and Basilisk) subjected to free aluminium toxicity, and to verify if this evaluation method would be useful for the selection of tolerant cultivars.

\section{Material and Methods}

Three seed lots from six Urochloa brizantha cultivars (Basilisk, Marandu, MG4, MG5, BRS Piatã, and Xaraés) were assayed using five concentrations of aluminium $\left(0,1,2,4\right.$, and $\left.8 \mathrm{mmol}_{\mathrm{c}} \mathrm{dm}^{3} \mathrm{Al}^{3^{+}}\right)$with four repetitions for germination. The best one of each was selected and used in the whole experiment.

\subsection{Germination Assay (GA)}

The seeds were germinated under stressful conditions simulated in laboratory using aluminium trichloride solutions $\left(0,399.6,799.2,1598.4\right.$, and $\left.3196.8 \mathrm{AlCl}_{3} \mathrm{mg} \mathrm{L}^{-1}\right)$ to obtain five aluminium stress levels (Custódio et al., 2002).

Germination was conducted in plastic boxes, over moistened paper, with water (i.e. no $\mathrm{Al}^{3^{+}}$, control), or with the different $\mathrm{Al}^{3^{+}}$solutions representing the different levels of stress, at ratios of 2.5 times the paper mass. Experiments were conducted with four replications of 100 seeds per treatment, in chambers under alternated temperature of $15-35^{\circ} \mathrm{C}$, with $8 \mathrm{~h}$ of light during the higher temperature phase. Evaluation was conducted for 14 days, and included counting primary root protrusion, normal and abnormal seedlings, and non-germinated seeds, according to Brasil (2009). Data are expressed as percentages.

Seedling development was measured using four repetitions of 15 seeds per treatment (Nakagawa, 1999). Seeds 
were wrapped in three sheets of germination paper $\left(\mathrm{Germitest}^{\circledR}\right)$, which included two as a base, and one as a cover, and paper were moistened with 2.5 times their mass, as previously described for germination. Seeds were placed in a line at $10 \mathrm{~cm}$ from the upper edge of the base sheets. Evaluation was conducted for 14 days after placing the rolls of seeds in polyethylene bags in a germinator, and the evaluations were the same as for the germination test. Length was measured using a graduated ruler $(\mathrm{mm})$ and all seedlings were measured individually. Mass was obtained by combining all seeds in each repetition, placing these in soft paper bags, and drying them with air circulation at $60{ }^{\circ} \mathrm{C}$ for $48 \mathrm{~h}$. After drying, materials were cooled in a desiccator and weighed on an analytical balance accurate to $0.001 \mathrm{~g}$ (Nakagawa, 1999). Results are shown as shoot and root length, and dry weight of shoot and roots.

\subsection{Early Seedling Growth Assay (ESGA)}

For this, 800 seeds from each cultivar were germinated in paper moistened in water. On the seventh day after germination, uniform seedlings were selected to evaluate the effects of the aluminium stress (Echer et al., 2010). Fifteen seedlings were used for each repetition, per treatment. Another four repetitions of 15 seedlings were used to measure the initial dry mass of shoots and roots, as described above.

Aluminium stress was applied in seedlings that had grown for seven days, using paper rolls moistened with the respective $\mathrm{Al}^{3+}$ solutions. Seedlings were placed in a line at $10 \mathrm{~cm}$ from the upper edge of the base sheet; the tops of leaves and roots were marked with a pencil on the moistened paper, and scored. The rolls were placed in polyethylene bags and kept at $25{ }^{\circ} \mathrm{C}$ for seven days. The seedlings were evaluated after that, by measuring the final length of shoots and roots. The dry mass of the seedlings was obtained as described above. The relative growth rates were calculated using the equation in Hunt (1982), with some changes (Equation 1).

$$
\mathrm{R}=\frac{\left(\ln \mathrm{W}_{2}-\ln \mathrm{W}_{1}\right)}{\mathrm{t}_{2}-\mathrm{t}_{1}}
$$

Where, $\mathrm{R}=$ relative growth rate; $\mathrm{ln}=$ natural logarithm; $\mathrm{W}_{1}=$ initial length or dry mass; $\mathrm{W}_{2}=$ final length or dry mass; $t_{1}=$ initial time and $t_{2}=$ final time. Data on relative growth rate are expressed as $\mathrm{cm} \mathrm{day}^{-1}$ or $\mathrm{g} \mathrm{day}^{-1}$.

Another four repetitions of 15 plants were used for biochemical analysis, including superoxide dismutase activity (SOD), and concentrations of proline, total antioxidants (TEAC), and malondialdehyde (MDA) were evaluated.

\subsection{Enzyme Extraction and Analysis}

Seedlings (approximately $0.2 \mathrm{~g}$ of fresh tissue) were collected at appropriate times. These were ground at $4{ }^{\circ} \mathrm{C}$ in $0.1 \mathrm{M}$ sodium phosphate buffer ( $\mathrm{pH} 7.8$ ) containing $0.4 \mathrm{~g}$ polyvinilpirrolidone, $2 \mathrm{mM}$ dithiothreitol, $0.1 \mathrm{mM}$ EDTA, and $1.25 \mathrm{mM}$ PEG4000. Extracts were centrifuged at 12,000 $\mathrm{g}$ for 20 minutes, and the supernatant was divided into four aliquots. One aliquot was used for protein quantitation (Bradford 1976), and the remaining aliquots were immediately analysed or stored at $-80^{\circ} \mathrm{C}$, and used to measure the enzyme described below.

\subsubsection{Superoxide Dismutase (SOD, EC.1.15.11)}

SOD activity was measured in seedlings subjected to $\mathrm{Al}^{3+}$ stress for seven days, using the method described in Moriya et al. (2015). One unit of SOD (mg protein $\left.{ }^{-1}\right)$ was defined as the enzyme activity able to inhibit the NBT photoreduction to blue formazan by $50 \%$. SOD data were normalized by protein content, determined by the Bradford (1976) method.

\subsection{Proline Content}

Three replicates of $300 \mathrm{mg}$ of seedlings collected seven days after the start of $\mathrm{Al}^{3+}$ stress were analysed for proline concentrations following the method of Bates et al. (1973). The proline concentration was plotted against a calibration curve, and expressed as $\mu \mathrm{g} \mathrm{g}^{-1}$ of dried tissue.

\subsection{Trolox Equivalent Antioxidant Capacity (TEAC)}

The extracts obtained from $100 \mathrm{mg}$ of leaves of seedlings subjected to $\mathrm{Al}^{3+}$ stress for seven days were homogenized in $2 \mathrm{ml}$ of methanol $50 \%(\mathrm{v} / \mathrm{v})$, which was kept at room temperature for $1 \mathrm{~h}$ and centrifuged. The supernatant was transferred to a new tube, and $2 \mathrm{ml}$ of acetone $70 \%(\mathrm{v} / \mathrm{v})$ was added to the pellet, incubated for 1 $\mathrm{h}$, and centrifuged. The supernatants were mixed, and the volume completed to $5 \mathrm{ml}$ with distilled water. $\mathrm{ABTS}^{+}$ radical was prepared by adding $88 \mu \mathrm{L}$ of potassium persulfate $140 \mathrm{mM}$ in $5 \mathrm{ml}$ of $7 \mathrm{mM}$ ABTS. The solution was kept in the dark for $12-16 \mathrm{~h}$ to complete oxidation of $\mathrm{ABTS}$ to $\mathrm{ABTS}^{+}$, and was subsequently diluted with $100 \%$ ethanol, until it reached 0.700 of absorbance $( \pm 0.020)$ at $734 \mathrm{~nm}$ (Re et al., 1999).

The TEAC assay was performed by adding $10 \mu \mathrm{L}$ of the extract to $1 \mathrm{ml}$ of diluted solution of ABTS ${ }^{+}$radical. The solution was incubated for $30 \mathrm{~min}$ at $30{ }^{\circ} \mathrm{C}$, and then the absorbance was determined at $734 \mathrm{~nm}$ in a spectrophotometer. The results were compared to a Trolox solution standard curve in ethanol. Analyses were 
performed in triplicate, and the values are expressed as $\mathrm{mM}$ of Trolox equivalents per gram of fresh weight.

\subsection{Malondialdehide Content (MDA)}

To evaluate the concentration of MDA, we followed the methodology described by Heath and Packer (1968). One hundred $\mathrm{mg}$ of leaves, from seedlings subjected to $\mathrm{Al}^{3+}$ stress for seven days, were homogenized in $6.5 \mathrm{ml}$ of ethanol $80 \%(\mathrm{v} / \mathrm{v})$ and centrifuged. One $\mathrm{ml}$ of the extract was collected and transferred to a microtube containing $1 \mathrm{~mL}$ of thiobarbituric acid (TBA) $0.65 \%(\mathrm{p} / \mathrm{v})$ in trichloroacetic acid (TCA) 20\% (p/v). Samples were incubated at $95{ }^{\circ} \mathrm{C}$ for $25 \mathrm{~min}$, transferred to an ice bath, and centrifuged, before being measured in a spectrophotometer.

The MDA equivalents were calculated using Equation 2, as follows:

$$
M D A \text { equivalent }=\left[\left(\mathrm{A}_{532}-\mathrm{A}_{600}\right) \mid 155000\right] \times 10^{6}
$$

Where, $\mathrm{A}_{532}$ indicates the maximum absorbance of the complex MDA-TBA at $532 \mathrm{~nm} ; \mathrm{A}_{600}$ is the absorbance at $600 \mathrm{~nm}$, which corrects for non-specific chromogens; and 155,000 is the molar extinction coefficient for MDA. The assay was conducted with three repetitions, and data are expressed as nMol of MDA per gram of fresh weight.

\subsection{Statistical Analysis}

GA and ESGA were conducted and analysed as a completely randomised design, and the treatments were applied in a factorial scheme of $6 \times 5$ (cultivars $\times$ aluminium stress level), with four repetitions. The variables analysed for GA were germination by root protrusion (PRP), normal seedling germination (NSG), length and weight of shoots (SL and SDW), and length and weight of roots (RL and RDW). For ESGA, the variables analysed were relative growth rate of shoot (RGR-RL) and root length (RGR-SL), and the relative growth rate of shoot dry weight (RGR-SDM) and root (RGR-RDM), SOD, proline, TEAC and MDA.

The percentage data were transformed by $\arcsin \sqrt{X / 100}$, while the other data were not transformed prior to analysis. Following analysis of variance (ANOVA), data on cultivars were submitted to Tukey's multiple comparison test $(\mathrm{P}<0.05)$ using SISVAR software (Ferreira, 2008), while data on stress treatments were evaluated by polynomial regression. The significant equations $(\mathrm{P}<0.05)$ with the lower polynomial degree and higher determination coefficient $\left(\mathrm{R}^{2}\right)$ were chosen.

\section{Results}

\subsection{Germination Assay}

The variance analysis indicated that the germination, as evaluated by PRP and NSG, was not significantly affected by the interaction between cultivar and aluminium concentrations (Table 1). All other variables were affected by the cultivar $\times$ aluminium concentrations interaction (Table 1$)$.

Table 1. F Values of germination by root protrusion (GRP), of normal seedlings (GNS), shoot length (SL), root length (RL), shoot dry weight (SDW) and root dry weight (RDW) during the germination of six cultivars of $U$. brizantha as a function of different aluminium levels

\begin{tabular}{llllllll}
\hline SV & DF & GPN & RP & SL & RL & SDW & RDW \\
\hline Cultivar (A) & 5 & $9.93^{* *}$ & $7.38^{* *}$ & $14.42^{* *}$ & $14.43^{* *}$ & $13.68^{* *}$ & $13.83^{* *}$ \\
Treatment (B) & 4 & $13.69^{* *}$ & $9.29^{* *}$ & $65.92^{* *}$ & $301.32^{* *}$ & $20.86^{* *}$ & $155.20^{* *}$ \\
A $\times$ B & 20 & $1.59 \mathrm{~ns}$ & $1.34 \mathrm{~ns}$ & $7.53^{* *}$ & $12.14^{* *}$ & $2.78^{* *}$ & $7.27^{* *}$ \\
Error & 90 & & & & & \\
Mean & & 46.4 & 78.1 & 1.77 & 1.07 & 0.017 & 0.002 \\
CV\% & & 34.3 & 16.27 & 29.57 & 39.34 & 34.42 & 42.59 \\
\hline
\end{tabular}

Note. SV: Sources of variation. DF: degrees of freedom. Means for GRP, GNS in percentage; SL and RL in cm; SDW and RDW in grams. CV\%: coefficient of variation in percentage. **: $\mathrm{P}<0.01$; ns: not significant.

For PRP, the average at level zero of aluminium stress (i.e. control, only water) was $85.5 \%$, and this decreased by $2.48 \%$ with increasing aluminium concentrations (Figure 1B). This result suggests that most seeds were able to initiate primary root development, and were less sensitive to aluminium stress than other parameters. For NSG, the average at level zero of aluminium stress (i.e. control, only water) was $57.5 \%$, which decreased by $3.73 \%$ with increasing aluminium concentrations (Figure 1A). 


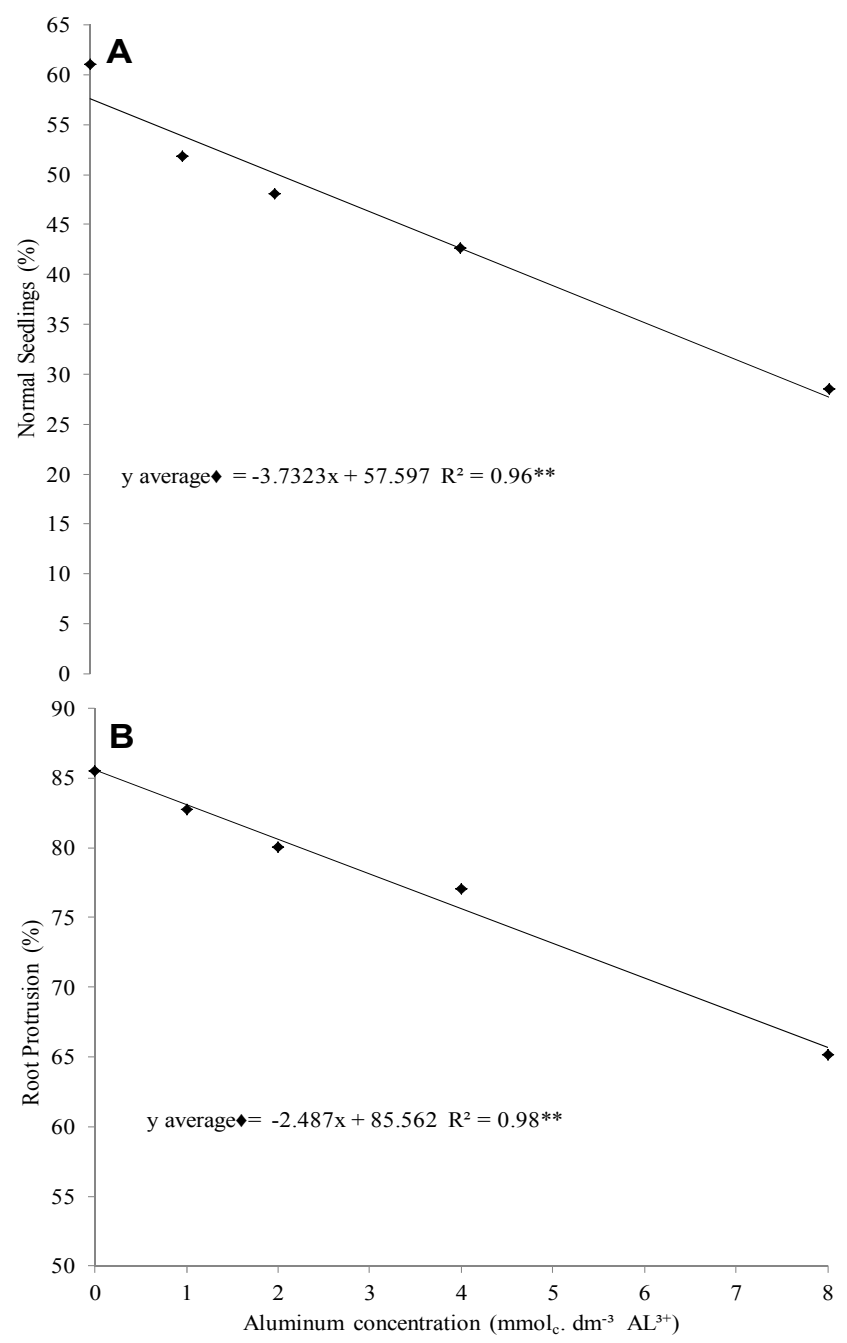

Figure 1. Normal seedling germination (NSG) (A) and root protrusion (PRP) (B) of $U$. brizantha seeds as a function of different aluminium levels

Cultivar MG5 was distinct from the other five cultivars, with a higher PRP (89.9\%) and NSG (55.65\%) (Table 2). On the other hand, cultivar Basilisk exhibited $24.6 \%$ of NSG as a response to the aluminium concentrations, and cultivars Marandu (67.65\%), Basilisk (72.6\%) and Xaraés (76.6\%) exhibited relatively high rates of PRP.

Table 2. Normal seedling germination (NSG) and primary root protrusion (PRP) of U. brizantha as a function of different aluminium dose

\begin{tabular}{lll}
\hline Cultivar & NSG $(\%)$ & PRP $(\%)$ \\
\hline MG-5 & $55.65 \mathrm{a}$ & $89.90 \mathrm{a}$ \\
Piatã & $40.35 \mathrm{a}$ & $81.70 \mathrm{ab}$ \\
MG-4 & $51.15 \mathrm{a}$ & $80.15 \mathrm{ab}$ \\
Xaraés & $71.70 \mathrm{a}$ & $76.60 \mathrm{bc}$ \\
Basilisk & $24.60 \mathrm{~b}$ & $72.60 \mathrm{bc}$ \\
Marandu & $44.95 \mathrm{a}$ & $67.65 \mathrm{c}$ \\
\hline
\end{tabular}

Note. ${ }^{1}$ Means followed by the same letter are not different by Tukey's test $(\mathrm{p}<0.05)$.

In relation to shoot length (SL, Figure 2A) there was a linear adjustment from $2.08 \mathrm{~cm}$ at level zero of aluminium stress (i.e. control, only water), with a decrease of $0.2 \mathrm{~cm}$ with increases in the aluminium concentrations for the Basilisk cultivar, and $1.8 \mathrm{~cm}$ with a decrease of $0.11 \mathrm{~cm}$ for the Xaraés cultivar. Cultivars 
MG4, MG5, and Marandu showed a quadratic adjustment with minima at $6.28,5.93$, and $6.71 \mathrm{mmol}_{\mathrm{c}} \mathrm{dm}^{-3} \mathrm{of}$ $\mathrm{Al}^{3^{+}}$, respectively. The Piatã cultivar, however, exhibited a quadratic adjustment with a maximum point at 3.39 $\mathrm{mmol}_{\mathrm{c}} \mathrm{dm}^{-3} \mathrm{Al}^{3^{+}}$. According to the LSD calculated by the average comparison test, at zero and $1 \mathrm{mmol}_{\mathrm{c}} \mathrm{dm}^{-3} \mathrm{Al}^{3^{+}}$, MG4 and MG5 had superior shoot lengths, whereas there were no differences between cultivars at 2, 4, and 8 $\mathrm{mmol}_{\mathrm{c}} \mathrm{dm}^{-3} \mathrm{Al}^{3^{+}}$.

For root length (Figure 2B), the effect of the aluminium concentrations were significant for all cultivars. Basilisk, MG4, MG5, Marandu, Piatã, and Xaraés cultivars exhibited a quadratic adjustment with minima at 5.49, 5.22, $5.55,5.44,5.81$, and $5.84 \mathrm{mmol}_{\mathrm{c}} \mathrm{dm}^{-3} \mathrm{Al}^{3^{+}}$respectively. According to the LSD from the average comparison test, cultivars MG4 and MG5 had the highest root length in the absence of aluminium (control conditions). For 1 $\mathrm{mmol}_{\mathrm{c}} \mathrm{dm}^{-3} \mathrm{Al}^{3^{+}}$, cultivars MG5 and Xaraés had a larger root system than the Basilisk cultivar, which had the shortest root system. We also observed that root length was more highly inhibited than shoot length in the presence of aluminium.

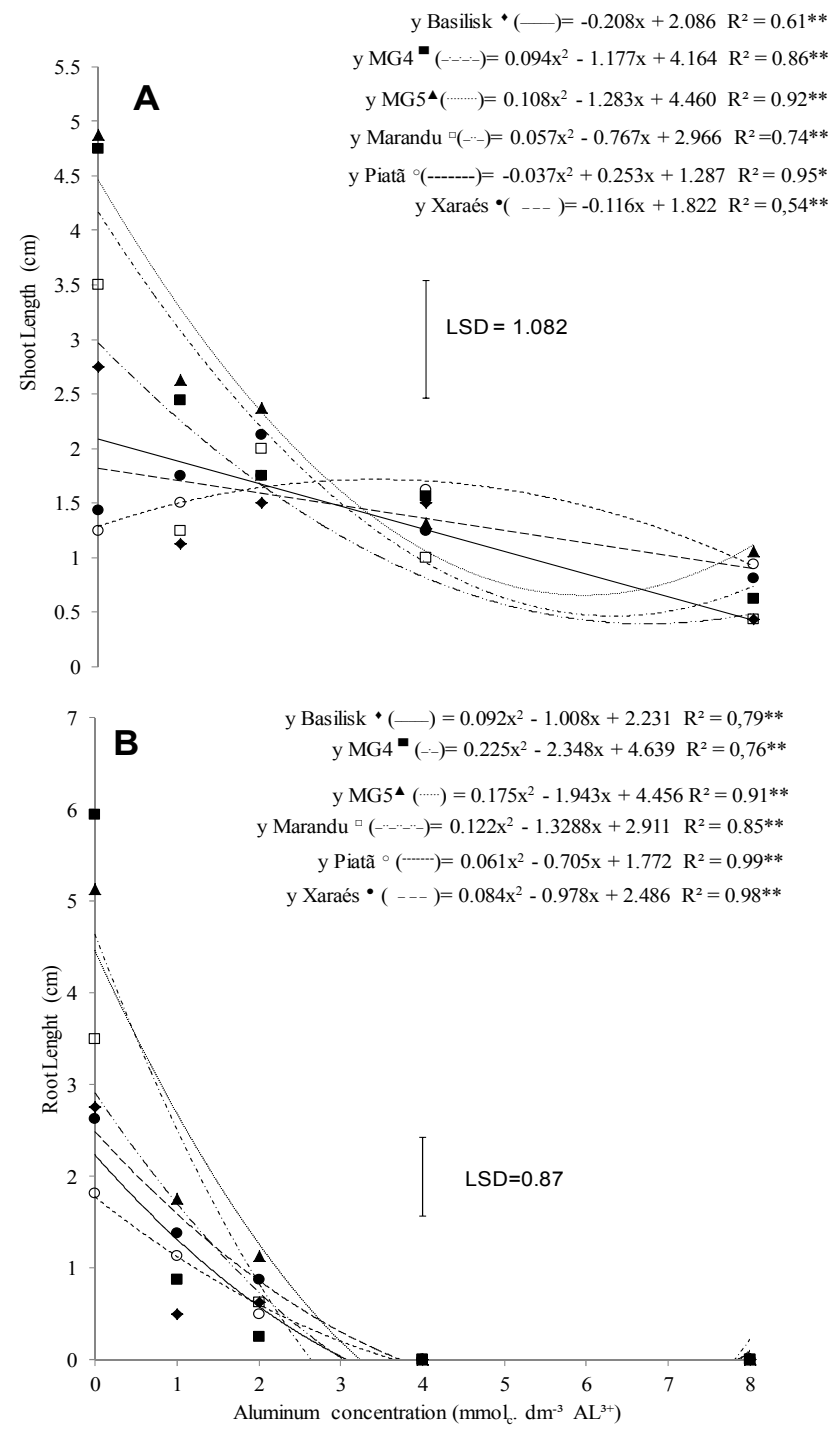

Figure 2. Shoot length (A) and root length (B) of six cultivars of $U$. brizantha seedlings as a function of different aluminium levels. Least Significant diference (LSD) at Tukey's test $(p<0.05)$

For shoot dry mass (Figure 3A), cultivars Basilisk, MG4, Marandu, and Xaraés had average weights of 0.0138, $0.0239,0.0211$, and $0.0243 \mathrm{~g}$ respectively, under control treatments (i.e. no aluminium), with a decrease of $0.0011,0.0026,0.0021$, and $0.0011 \mathrm{~g}$ for each increase in the aluminium concentration. Nevertheless, the data 
for cultivar MG5 adjusted quadratically, with a minimum at $6.12 \mathrm{mmol}_{\mathrm{c}} \mathrm{dm}^{-3} \mathrm{Al}^{3^{+}}$, and the Piatã cultivar had a quadratic adjustment with a maximum point at $3.2 \mathrm{mmol}_{\mathrm{c}} \mathrm{dm}^{-3} \mathrm{Al}^{3+}$. Considering the LSD, cultivar MG5 had the highest SDW under the control treatment (i.e. no aluminium) and at $1 \mathrm{mmol}_{\mathrm{c}} \mathrm{dm}^{-3} \mathrm{Al}^{3^{+}}$. At the highest concentrations of $\mathrm{Al}^{3+}$, there were no differences in shoot dry mass between cultivars.

Regarding root dry mass (Figure 3B), the Basilisk cultivar had a mean dry root mass of $0.0023 \mathrm{~g}$ under the control treatment (i.e. no aluminium), which decreased by $0.0003 \mathrm{~g}$ for each increase in the aluminium concentration. Cultivars MG4, MG5, Marandu, Piatã, and Xaraés, showed a quadratic adjustment with minima at 4.83, 6.33, 4.75, 4.5, and $7.2 \mathrm{mmol}_{\mathrm{c}} \mathrm{Al}^{3^{+}} \mathrm{dm}^{-3}$. With $4 \mathrm{mmol}_{\mathrm{c}} \mathrm{dm}^{-3} \mathrm{Al}^{3^{+}}$, for example, the root mass of all cultivars decreased to zero, while there were still observable shoot masses (Figures 3A and 3B). The LSD obtained for root dry matter was 0.0019 (Figure 3B). Cultivars MG4 and MG5 exhibited the highest root dry masses under control treatments (i.e. no aluminium), which was very different from cultivars Xaraés and Basilisk. At the lowest $\mathrm{Al}^{3^{+}}$concentration $\left(1 \mathrm{mmol}_{\mathrm{c}} \mathrm{dm}^{3} \mathrm{Al}^{l^{+}}\right)$, cultivar MG5 was still superior. For the other $\mathrm{Al}^{3^{+}}$concentrations, there were no differences in dry root mass among cultivars.

\subsection{Early Seedling Growth Assay}

The F values of ANOVAs from this assay are shown in Table 3. The seedlings were standardized before the treatments started (seven days), and the seedlings depended only on the seed storage material for growth. There were no significant differences in the total seedling growth rates (data not shown), but there were significant differences observed in the RGR-SDW and RDW.

Regarding the biochemical parameters studied, differences in proline, SOD, and TEAC were mostly significant only in relation to cultivars. For MDA concentrations, there was significant effect of the interaction between cultivars and $\mathrm{Al}^{3+}$ concentrations.

Table 3. F Values of shoot length relative growth rate (RGR-SL), root length relative growth rate (RGR-RL), shoot dry weight relative growth rate (RGR-SDW), root dry weight relative growth rate (RGR-RDW), Proline, Superoxide Dismutase activity (SOD), Trolox equivalent antioxidant capacity (TEAC) and malondialdehyde quantification (MDA) of seedlings from six cultivars of Urochloa brizantha as a function of different aluminium levels

\begin{tabular}{|c|c|c|c|c|c|}
\hline \multirow{2}{*}{ SV } & \multirow{2}{*}{ DF } & \multicolumn{4}{|c|}{ Growth variables } \\
\hline & & RGR-SL & RGR-RL & RGR-SDW & RGR-RDW \\
\hline Cultivar (A) & 5 & $21.00^{* *}$ & $4.83^{* *}$ & $7.28^{* *}$ & $64.35^{* *}$ \\
\hline Treatment (B) & 4 & $47.79^{* *}$ & $14.50^{* *}$ & $3.24^{* *}$ & $8.28^{* *}$ \\
\hline $\mathrm{A} \times \mathrm{B}$ & 20 & $5.31^{* *}$ & $2.18^{* *}$ & $2.59^{* *}$ & $8.70^{* *}$ \\
\hline Error & 90 & & & & \\
\hline Mean & & 0.053 & 0.002 & 0.01 & 0.019 \\
\hline $\mathrm{CV} \%$ & & 24.8 & 182.9 & 69.31 & 51.01 \\
\hline \multirow{2}{*}{ SV } & \multirow{2}{*}{ DF } & \multicolumn{4}{|c|}{ Biochemical variables } \\
\hline & & Proline & SOD & TEAC & MDA \\
\hline Cultivar (A) & 5 & $16.28^{* *}$ & $12.75^{* *}$ & $28.72 * *$ & $22.60 * *$ \\
\hline Treatment (B) & 4 & $5.30^{\mathrm{ns}}$ & $1.60^{\mathrm{ns}}$ & $1.44^{\mathrm{ns}}$ & $5.77^{* *}$ \\
\hline $\mathrm{A} \times \mathrm{B}$ & 20 & $2.17^{\mathrm{ns}}$ & $1.15^{\mathrm{ns}}$ & $1.63^{\mathrm{ns}}$ & $4.76^{* *}$ \\
\hline Error & 90 & & & & \\
\hline Mean & & 5.76 & 0.001 & 5.75 & 0.56 \\
\hline $\mathrm{CV} \%$ & & 87.42 & 68.11 & 56.94 & 53.08 \\
\hline
\end{tabular}

Note. SV: source of variation; DF: degrees of freedom. Means for RGR-SL and RGR-RL in cm day ${ }^{-1}$; RGR-SDM and RGR-RDM in $g$ day $^{-1}$. average in percentage; Proline in $\mu \mathrm{g} \mathrm{g}^{-1}, \mathrm{SOD} \mathrm{mg}$ protein ${ }^{-1}$, TEAC mM equivalent trolox $\mathrm{g} \mathrm{FW}^{-1}$ and MDA in $\mathrm{nmol} \mathrm{g} \mathrm{MF}^{-1}$. $\mathrm{CV} \%$ coefficient of variation in percentage. 


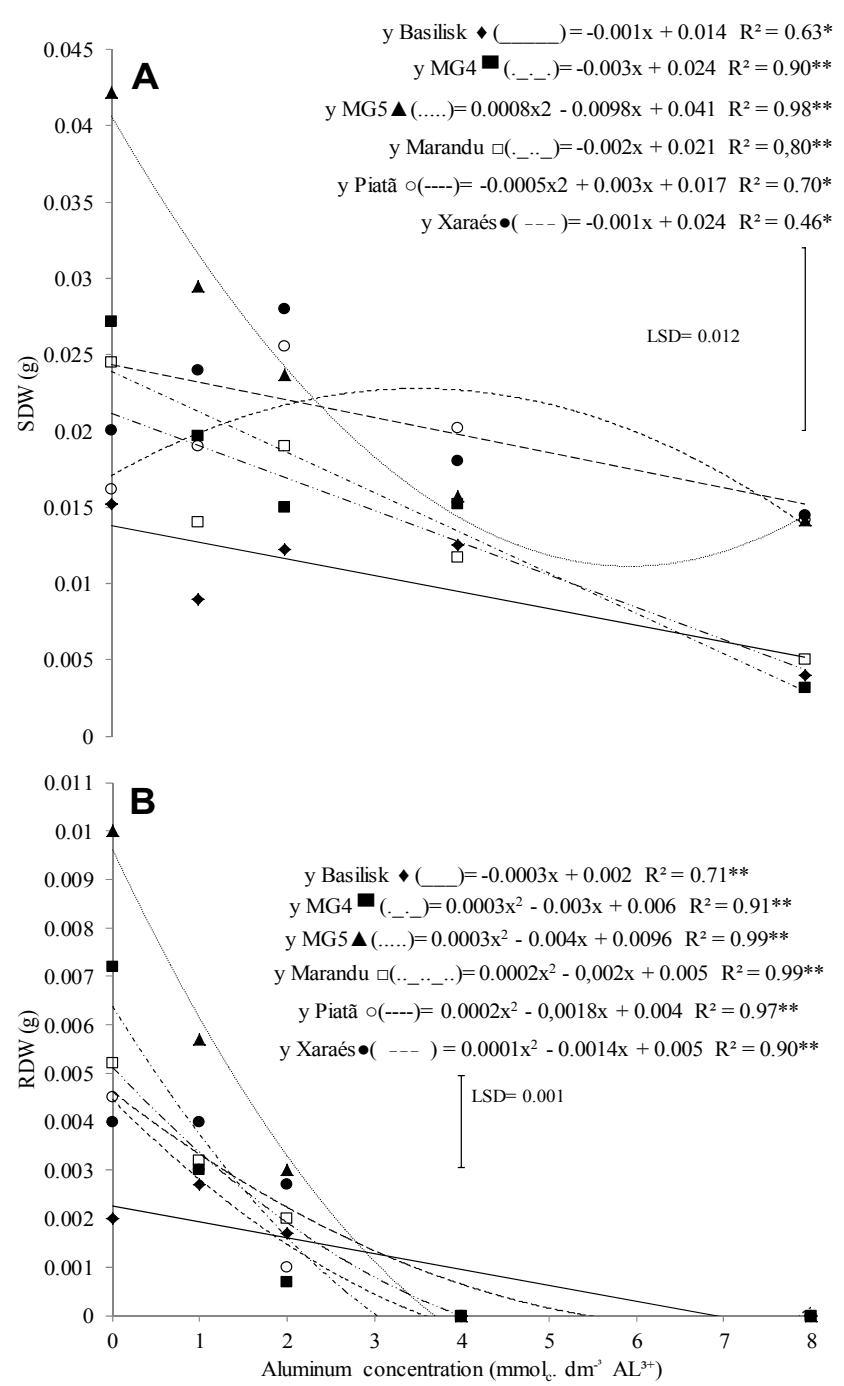

Figure 3. Shoot dry matter (SDM) (A) and root dry matter (RDM) (B) of six cultivars of $U$. brizantha seedlings as a function of different aluminium levels. Last Significant diference (LSD) at Tukey's test $(p<0.05)$

For RGR-SL (Figure 4A), cultivars Basilisk and Marandu showed a quadratic fit with minimum points calculated at 6.2 and $6.26 \mathrm{mmol}_{\mathrm{c}} \mathrm{dm}^{-3} \mathrm{Al}^{3+}$, respectively. The MG4, Piatã, and Xaraés cultivars exhibited a linear fit with average RGR-SL under control conditions (i.e. no aluminium) of $0.0689,0.0583$, and $0.0498 \mathrm{~cm} \mathrm{day}^{-1}$, which decreased by $0.0042,0.004$, and $0.0024 \mathrm{~cm}^{\text {day }}{ }^{-1}$ respectively, with each increase in the $\mathrm{Al}^{3^{+}}$ concentration. Cultivar MG5 did not show any variation in RGR-SL as a function of the increasing $\mathrm{Al}^{3+}$ concentrations during the stress period, indicating that the shoot growth was not affected by the $\mathrm{Al}^{3+}$ concentrations used in the experiment. Cultivar Marandu differed from cultivar Xaraés under the control treatment (i.e. no aluminium), and at $1 \mathrm{mmol}_{\mathrm{c}} \mathrm{dm}^{-3}$ of $\mathrm{Al}^{3}$, according to a LSD of $0.027(\mathrm{p}<0.05)$. At $4 \mathrm{mmol}_{\mathrm{c}}$ $\mathrm{dm}^{-3}$ of $\mathrm{Al}^{3^{+}}$, however, cultivars MG5 and MG4 differed from the Basilisk cultivar. At $8 \mathrm{mmol}_{\mathrm{c}} \mathrm{dm}^{-3} \mathrm{of} \mathrm{Al}^{+{ }^{+}}$, only cultivar MG5 differed from the Basilisk cultivar.

Regarding RGR-RL (Figure 4B), only cultivars MG4, MG5, and Xaraés exhibiting a significant quadratic fit, with minima at 5.12, 6.16, and $6 \mathrm{mmol}_{\mathrm{c}} \mathrm{dm}^{-3} \mathrm{Al}^{3^{+}}$. Cultivars Basilisk, Marandu, and Piatã did not show variation in this parameter as a function of increasing $\mathrm{Al}^{3^{+}}$concentrations. In this case, cultivar Xaraés, in the absence of $\mathrm{Al}^{3+}$, was the cultivar with the most elongated roots, whereas cultivar Basilisk had the least root growth $(\mathrm{p}<$ 0.05). At $1 \mathrm{mmol}_{\mathrm{c}} \mathrm{dm}^{-3}$ of $\mathrm{Al}^{3+}$, only cultivar Xaraés had root growth differing from the other cultivars. 


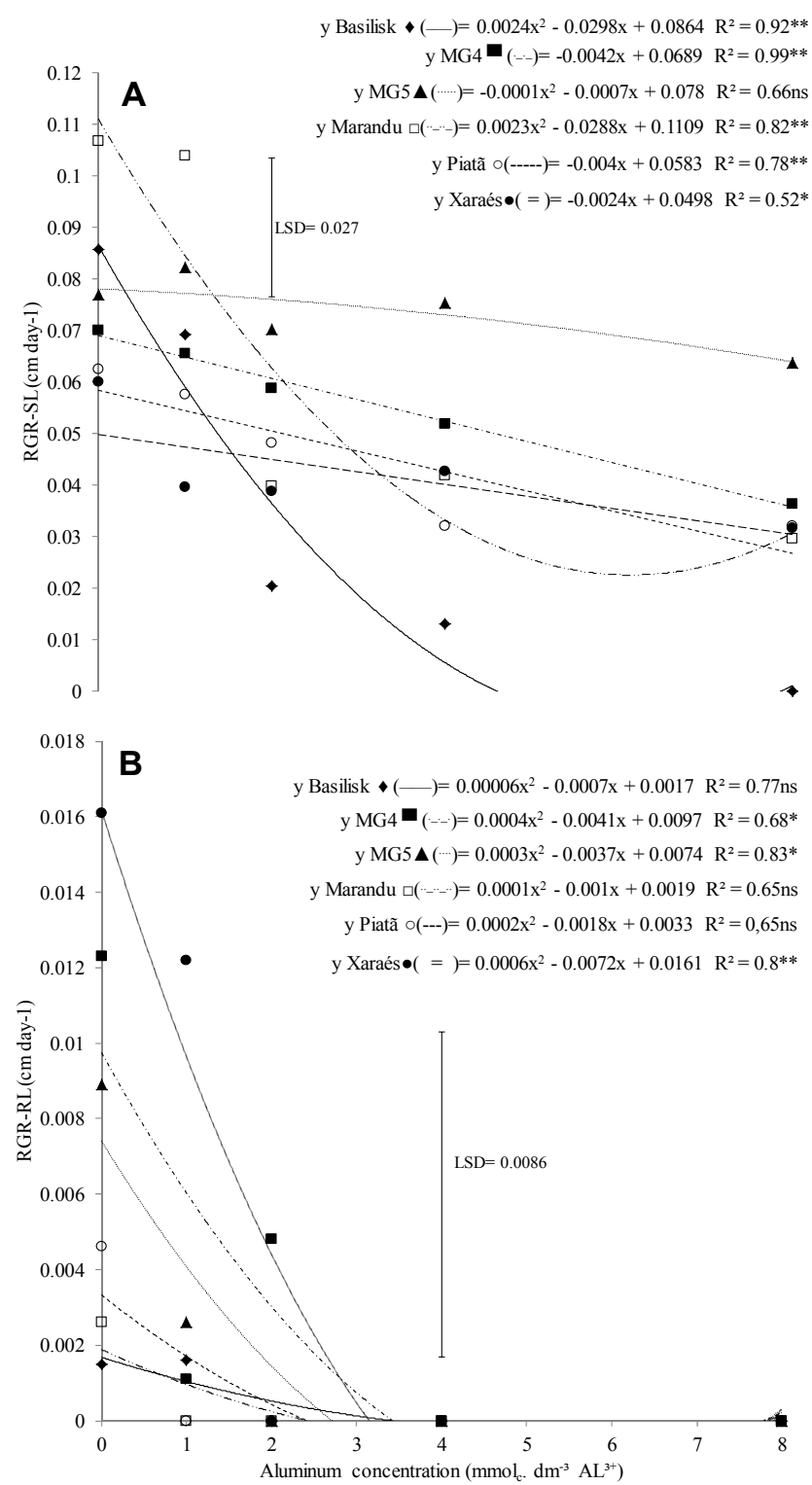

Figure 4. Relative Growth Rate of shot length (RGR-SL) (A) and root length (RGR-RL) (B) of six cultivars of $U$. brizantha seedlings as a function of different aluminium concentrations. Least Significant diference (LSD) at Tukey's test $(\mathrm{p}<0.05)$

For the parameter RGR-SDM (Figure 5A), cultivars Basilisk and Xaraés exhibited a linear fit with an initial mean of 0.0135 and $0.0144 \mathrm{~g} \mathrm{day}^{-1}$ (under control conditions), decreasing by, respectively, 0.0019 and $0.0013 \mathrm{~g}$ day $^{-1}$ for each increase in aluminium concentration. Cultivars MG4 and Marandu showed a quadratic fit with a maximum at $4.1 \mathrm{mmol}_{\mathrm{c}} \mathrm{dm}^{-3}$ and a minimum at $5.5 \mathrm{mmol}_{\mathrm{c}} \mathrm{dm}^{3}$ of $\mathrm{Al}^{+}$, respectively. Cultivars MG5 and Piatã did not have any response to increasing $\mathrm{Al}^{3+}$ concentrations. Cultivar Xaraés translocated more mass from seed food reserves to the shoots, which was different from cultivar MG5, which translocated less mass from seed food reserves to the shoots under control conditions. At 1 and $2 \mathrm{mmol}_{\mathrm{c}} \mathrm{dm}^{-3} \mathrm{of} \mathrm{Al}^{3+}$, there were no differences between cultivars. At $4 \mathrm{mmol}_{\mathrm{c}} \mathrm{dm}^{-3}$ of $\mathrm{Al}^{3+}$, cultivars Xaraés and MG4 differed from cultivars Basilisk and Marandu, with the highest and lowest translocation rates for shoots grown in the presence of $\mathrm{Al}^{l^{+}}$.

For RGR-RDM (Figure 5B), cultivars Basilisk and Xaraés exhibited a linear fit, with initial averages of 0.0312 and $0.0059 \mathrm{~g} \mathrm{day}^{-1}$ (under control conditions), which decreased by 0.0045 and $0.0005 \mathrm{~g}$ day $^{-1}$ respectively, for each increase in aluminium concentration. Cultivars MG4 and Marandu otherwise showed a quadratic fit with a minimum at $3.6 \mathrm{mmol}_{\mathrm{c}} \mathrm{dm}^{-3}$ and a maximum at $4.4 \mathrm{mmol}_{\mathrm{c}} \mathrm{dm}^{-3}$ of Al $^{3+}$, respectively. Cultivars MG5 and Piatã 
were not influenced by $\mathrm{Al}^{3+}$ at the concentrations included in this study. The cultivars did not differ regarding reserve translocation for the root growth in mass in the absence of aluminium and at the lower aluminium concentration. At $4 \mathrm{mmol}_{\mathrm{c}} \mathrm{dm}^{-3}$ of $\mathrm{Al}^{3+}$, cultivars Basilisk and Marandu were able to translocate more mass to the roots than the other cultivars. Cultivars Basilisk and Marandu, in the presence of aluminium, translocated reserves to root growth, jeopardizing the shoot growth, which can be understood as a tolerance reaction. Cultivars Xaraés and MG5 did the opposite (Figure 5A).

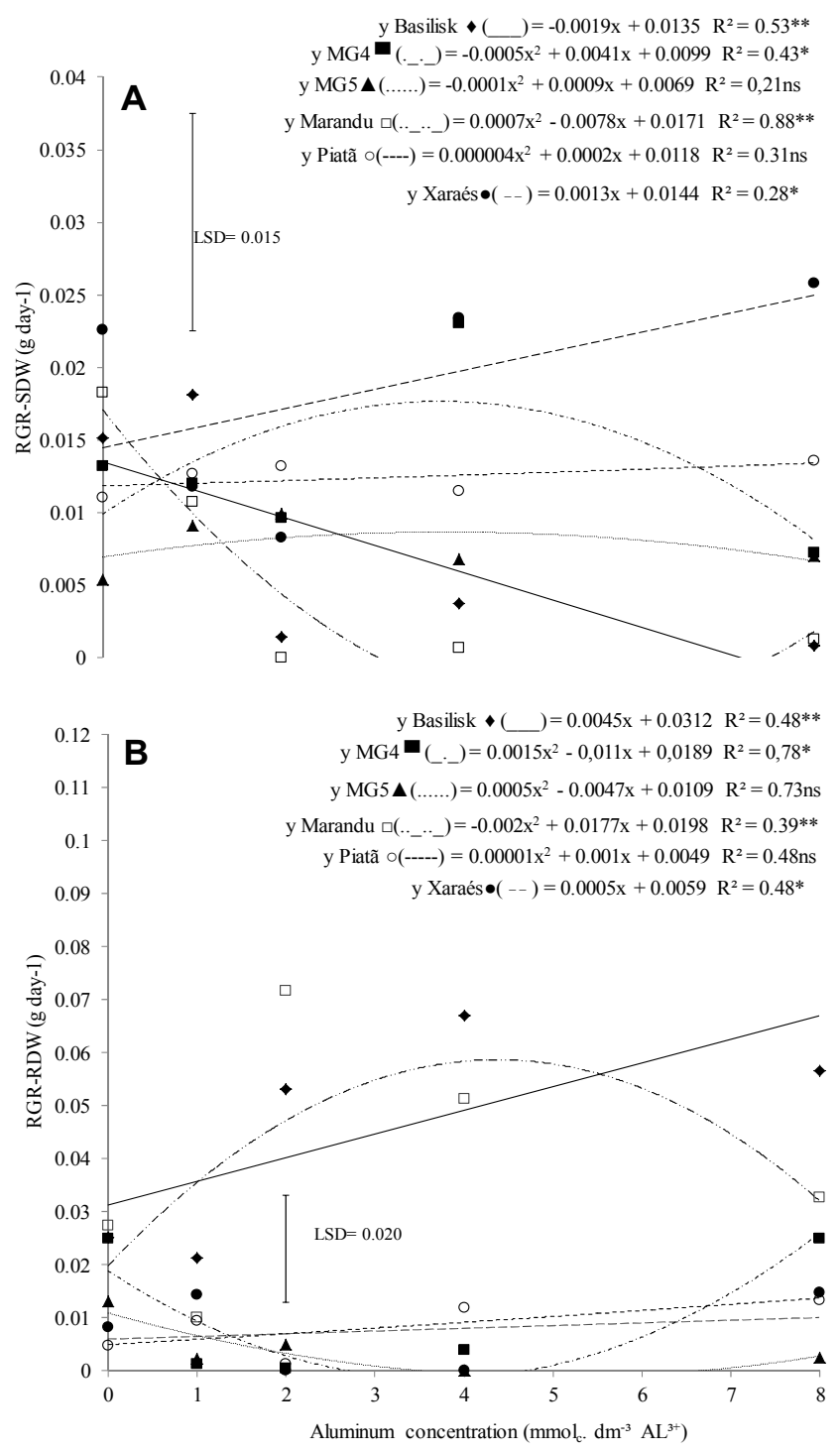

Figura 5. Relative Growth Rate of shoot dry matter (RGR-SDM) (A) and of root dry matter (RGR-RDM) (B) of six cultivars of $U$. brizantha seedlings as a function of different aluminium levels. Least Significant difference (LSD) at Tukey's test $(\mathrm{p}<0.05)$

Regarding proline concentrations, there was no significant effect of the $\mathrm{Al}^{3+}$ treatments. Cultivar Xaraés had the highest concentration of proline, with $15.327 \mu \mathrm{g} \mathrm{g}^{-1}$ (Table 4). Cultivar Marandu, with $0.498 \mu \mathrm{g} \mathrm{g}^{-1}$ of proline, had the lowest average concentration of proline, but this was not significantly different from that in cultivars Basilisk, MG4, and MG5. The same pattern was found for the SOD activity. 
Table 4. Proline determination (Proline), Superoxide Dismutase activity (SOD) and Trolox equivalent antioxidant capacity (TEAC) of Urochloa brizantha seedlings as a function of different aluminium levels

\begin{tabular}{|c|c|c|c|}
\hline Cultivar & PROLINE & SOD & TEAC \\
\hline & ------- $\mu \mathrm{g} \mathrm{g}^{-1}$------- & ------ mg protein ${ }^{-1}$------ & -- mM equivalent trolox $\mathrm{g} \mathrm{FW}^{-1}$-- \\
\hline Basilisk & $2.00 \mathrm{bc}$ & $0.00107 \mathrm{bc}$ & $5.430 \mathrm{~b}$ \\
\hline MG4 & $4.03 \mathrm{bc}$ & $0.00064 \mathrm{bc}$ & $11.733 \mathrm{a}$ \\
\hline MG5 & $5.71 \mathrm{bc}$ & $0.00127 \mathrm{~b}$ & $10.684 \mathrm{a}$ \\
\hline Marandu & $0.49 \mathrm{c}$ & $0.00043 \mathrm{c}$ & $2.484 \mathrm{bc}$ \\
\hline Piatã & $7.00 \mathrm{~b}$ & $0.00054 \mathrm{bc}$ & $0.500 \mathrm{c}$ \\
\hline Xaraés & $15.32 \mathrm{a}$ & $0.00215 \mathrm{a}$ & $3.685 \mathrm{bc}$ \\
\hline
\end{tabular}

Note. Means with the same letter did not differ at Tukey's test at $5 \%$ of confidence.

There were interaction effects between cultivars and aluminium concentrations on concentrations of MDA in the plants. Cultivar MG4 had the highest response (Figure 6) to increases in aluminium concentrations. The other cultivars did not have the same response to aluminium concentrations. MDA is an intermediary of lipid peroxidation and cell membrane disruption. This result might be explained as a function of the high sensitivity of the MG4 cultivar to the aluminium, because there was an increase in shoot growth to the detriment of the root, which was inhibited by the aluminium in the substrate (Figure $5 \mathrm{~A}$ ), until aluminium concentrations of $4.1 \mathrm{mmol}_{\mathrm{c}}$ $\mathrm{dm}^{-3} \mathrm{Al}^{3^{+}}$.

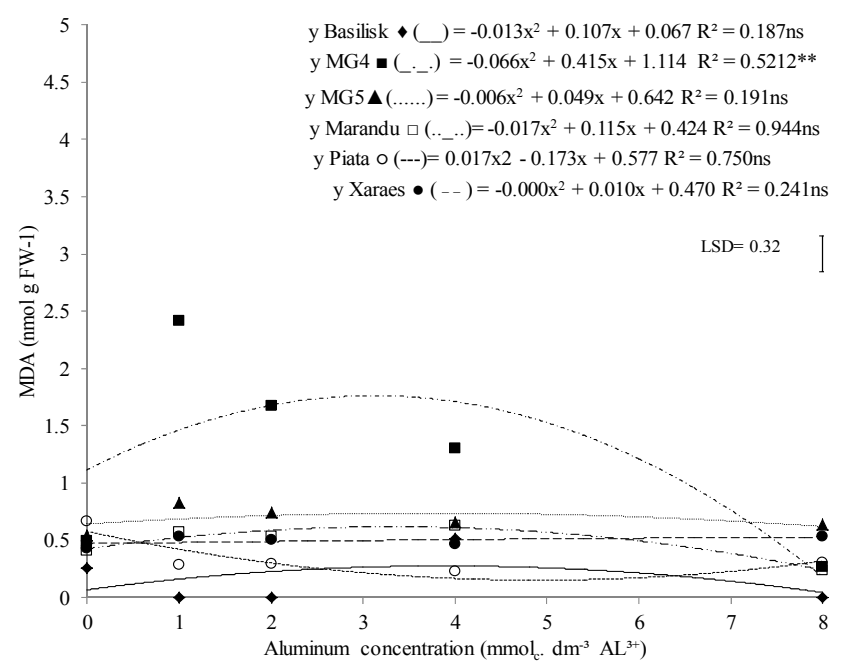

Figure 6. Malondialdheyde quantification (MDA) in fresh tissue of $U$. brizantha seedlings as a function of different aluminium. Least Significant difference (LSD) at Tukey's test 5\%

The differences between the cultivars are shown in Figure 7, which is a dendrogram using the UPGMA method comparing the cultivars using several variables from both experiments. The GA showed that cultivars are very close to each other (from 0.065 to 0.0054 ), and this could indicate that all the initial growth was maintained for the endosperm, so did not reflect the real differences between cultivars. The variables measured in the seedling development stage increase the differences between the cultivars, which are expected in materials differing in their responses to the environment. In the specific case of the Basilisk cultivar (U. brizantha, Miles et al., 1996; Ambiel et al., 2010), considered by many to be $U$. decumbens, it was the cultivar that differed the most from the other cultivars. For the cultivar pair MG5/BRS-Xaraés, which were registered from the same accession from CIAT (RNC, 2018), it could be seen that they presented some divergences, which would indicate that they could not be the same genotypes. But for the purposes of genotype selection, the second methodology, e.g., ESGA, would be more effective, nevertheless it also must be tested in adult plants. 

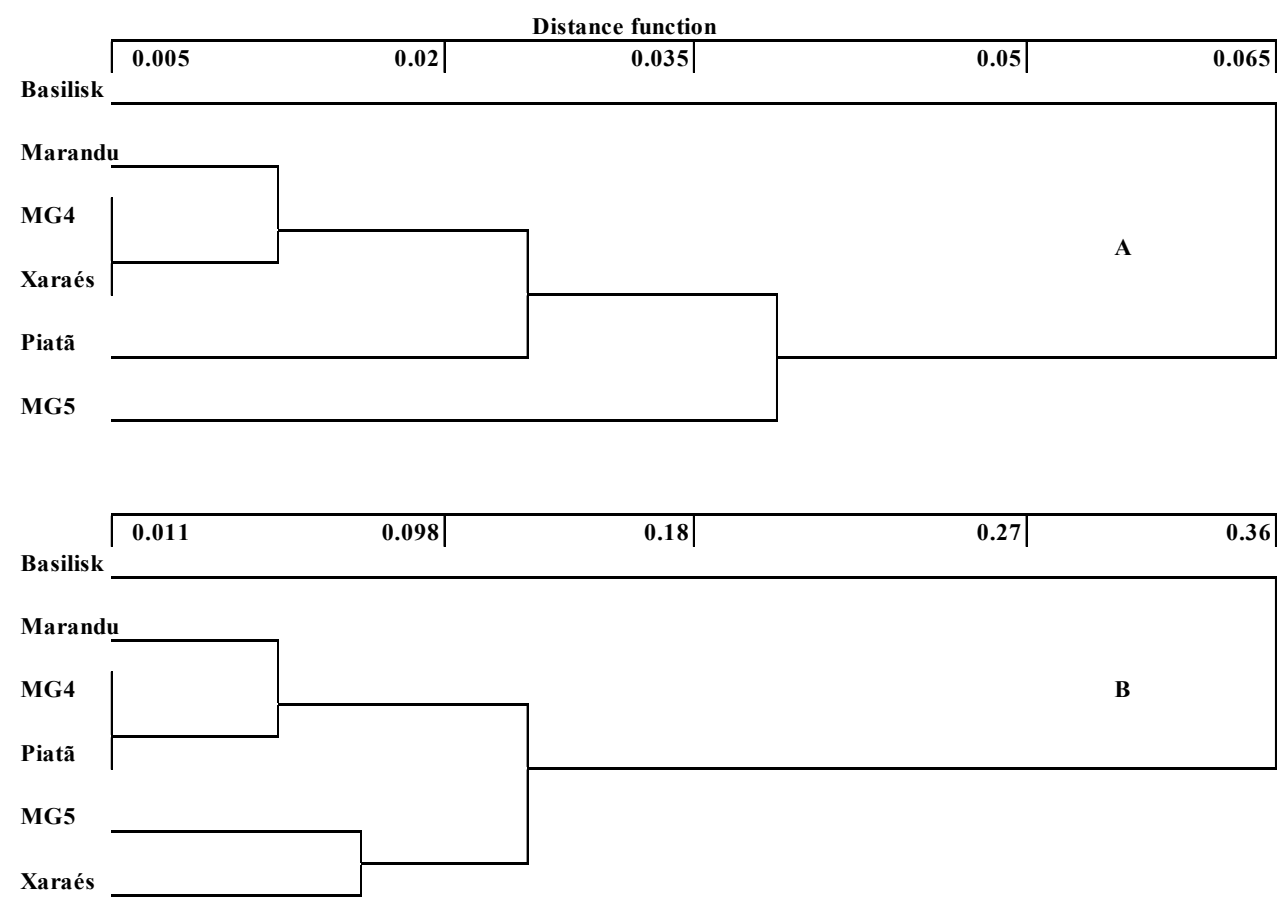

Figure 7. Dendrogram of six $U$. brizantha cultivars for aluminium tolerance using the variables germination (root protrusion and normal seedlings), shoot and root (length and dry weight) (GA-A) and and Relative growth length of shoot and root (length and dry weight) (ESGA-B)

\section{Discussion}

Roots are the plant tissue that is most sensitive to aluminium toxicity because they are constantly in contact with the element. Aluminium resistance can be explained as a mechanism that allows the plant to maintain growth even in the presence of aluminium (Liu et al., 2014). Aluminium resistance can be split in two sub-mechanisms: a) aluminium avoidance: the plant leaks organic acids (citrate, malate, or oxalate) into the rhizosphere, preventing the $\mathrm{Al}^{3+}$ from reaching the root tips, and keeping it as a chelate (Delhaize et al., 1993a, 1993b; Ma et al., 2001, 2014); and b) aluminium tolerance: which means that the plant may accumulate the element in the exodermis cell walls (Arroyale et al., 2011, 2013), or take up aluminium and immobilize it in the vacuoles. In gramineous crops of commercial importance, including some Triticinae (Delhaize et al., 1993a, 1993b; Ma et al., 2001, 2014), maize (Giannakoula et al., 2010), and rice (Kikui et al., 2005; Roselló et al., 2015), this phenomenon is very well studied.

At the germination stage $(<5 \mathrm{~mm})$, presence of $\mathrm{Al}^{3+}$ in the media strongly inhibited the root system growth of a hypersensitive mutant of rice, but not in its absence. Thus, rice possesses Al-tolerant function that is under genetic control in the beginning of the root growth, making rice more tolerant to $\mathrm{Al}^{3+}$ than wheat (Kikui et al., 2005). Therefore, root growth should be preferentially targeted as a parameter of aluminium tolerance (Tamas et al., 2006; Rosado et al., 2012; Silva, 2012; Too et al., 2014; Rao et al., 2016) and each crop has an optimum stage to be used.

Rao et al. (2006) showed that the Basilisk cultivar is highly resistant to $\mathrm{Al}^{3+,}$ and that the level of this resistance is far superior to cultivated varieties of crops such as maize, upland rice, or wheat (Wenzl et al., 2001). The results presented by Arroyave et al. $(2011,2013)$ indicated that concentrations of $200 \mu \mathrm{mol} \mathrm{L} \mathrm{L}^{-1}$ of $\mathrm{AlCl}_{3}(32$ $\mu \mathrm{mol} \mathrm{L} \mathrm{L}^{-1}$ of $\mathrm{Al}^{3+}$ ) are necessary to decrease the root growth of Urochloa brizantha pastures. For the Basilisk cultivar (a cultivar of $U$. brizantha), the same concentration did not affect the root elongation, either by the exclusion of the aluminium in the multiseriate exodermis, or by the aluminium depositions in hot spots along the root hairs, which is considered a hyperresistance to aluminium. However, in the Marandu cultivar (palisade grass, also an U. brizantha cultivar) aluminium was distributed in the cell walls of the root tips (Arroyave et al., 2011). The results found in this study, for both the GA (Tables 1 and 2, Figures 1, 2 and 3) and for the ESGA (Table 3, Figures 4 and 5) support the idea that the Basilisk cultivar is aluminium stress tolerant.

An assay carried out by Matins et al. (2011) demonstrated that a gradual increase in aluminium concentration in 
the solution affected the shoot dry matter production of $U$. ruziziensis, but not of $U$. brizantha and $U$. dictyoneura (Haussler et al., 2006). On the other hand, there were very strong differences in root growth rates between 30 Panicum maximum genotypes (Almeida et al., 2000). Nolla et al. (2007) studied effects of aluminium on soybeans, and found declines in both shoot and root dry matter when the aluminium concentration increased. However, at lower doses, aluminium could have a stimulatory effect on the early growth of soybeans (Custódio et al., 2002). Though, after a certain limit, there was a decrease in the root growth and an increase in the shoot growth. This could be easily explained as a shift in the source:sink balance. The energy stored in the seed is used to increase shoots and roots; but if the root is not using the energy for growth, this energy would be available for increased growth of shoots. As such, a susceptible plant would have an impaired growth ratio of shoot:root, and a tolerant plant would have a slight decrease in the root growth. Furthermore, in this study, for both the GA (Figures $2 \mathrm{~B}$ and $3 \mathrm{~B}$ ) and the ESGA, better results regarding aluminium tolerance were found in the root parameters (relative growth rates of length-Figure 4B or, dry weight-Figure 5B).

For the GA, the methodology indicated that the seed initial quality was a problem, because it may interfere in the evaluation of $\mathrm{Al}^{3+}$ tolerance, and increasing levels of $\mathrm{Al}^{3+}$ were detrimental to germination. Cultivar MG5 exhibited the highest seedling length under the control conditions (i.e. no aluminium), and at $1 \mathrm{mmol}_{\mathrm{c}} \mathrm{dm}^{-3} \mathrm{Al}^{3+}$ it showed the largest decrease in seedling length, indicating a low tolerance to this kind of stress. The Basilisk cultivar was the least affected by $\mathrm{Al}^{3^{+}}$stress, especially in the roots, which continued to grow, even with increasing $\mathrm{Al}^{3^{+}}$concentrations.

The ESGA avoids the confounding factor of the initial seed quality, and was more efficient in clearly separating the cultivars according to $\mathrm{Al}^{3+}$ tolerance. Until 14 days after sowing, the Basilisk cultivar was the most tolerant, and it was able to maintain growth of its root system under $\mathrm{Al}^{3+}$ stress conditions, although the growth rate decreased at the higher $\mathrm{Al}^{3+}$ concentrations. In contrast, the less tolerant cultivars reduced their root growth even at low concentrations of free aluminium, and developed proportionally more shoots, as the growth of shoots is based on the mobilization of the seed reserves. Xaraés, MG5, and MG4 cultivars were superior under control conditions, or at $1 \mathrm{mmol}_{\mathrm{c}} \mathrm{dm}^{-3} \mathrm{Al}^{3+}$, and the root mass of the Marandu cultivar increased until $4 \mathrm{mmol}_{\mathrm{c}} \mathrm{dm}^{-3} \mathrm{Al}^{3^{+}}$. Similar decreases in root growth in response to aluminium were found in Jatropha curcas (Rosado et al., 2012), sorghum (Too et al., 2014), and barley (Tamas et al., 2006) in studies that used a similar methodology (e.g., measuring the root growth in seedlings in paper rolls moistened with aluminium solutions). Studies using hydroponic (Giannakoula et al., 2010; Arroyave et al., 2011, 2013; Matins et al., 2011; Ramos et al., 2012; Roselló et al., 2015), semi-hydroponic (Colombo et al., 2016), and even growth in soil methods (Mutimura \& Everson, 2012) have found similar results, but these methods are expensive and time consuming.

Hare and Cress (1997) reported that proline accumulation occurred when wheat was exposed to water deficits, and therefore was a function of osmotic regulation and cellular protection. There were no increases in concentrations of proline in shoots and roots of sorghum when plants were exposed to aluminium alone, but an increase was found when aluminium stress and water deficits were applied simultaneously (Zaifnejad et al., 1997). The proline concentration decreased with increasing concentrations of aluminium in one sorghum variety (Cruz et al., 2011). Giannakoula et al. (2008) found that higher concentrations of proline, as well as carbohydrates, are not related to aluminium tolerance/resistance, but to osmoregulation and membrane stabilization. In the present study, U. brizantha cultivars, whether they were tolerant or susceptible to aluminium, did not exhibit a significant alteration in the proline concentrations induced by aluminium concentrations, although there were differences in the proline concentrations of the different cultivars (Table 4).

There was no significant relationship between SOD activity and the different concentrations of aluminium (Table 4). This differs from the results found by Hossain et al. (2011), who reported that wheat seeds exhibited a high SOD activity when exposed to aluminium, as compared with the controls. The results of the biochemical tests used to measure proline, SOD, and TEAC (Table 4) were not indicative of $\mathrm{Al}^{3+}$ toxicity. The results of MDA analysis were more promising (Figure 6). In the Xaraés cultivar, a high SOD activity and high proline concentration was detected with increasing concentrations of aluminium, although this relationship was not statistically significant. The high SOD activity and proline content could explain the low tolerance of this cultivar to the increments of aluminium in the substrate. In this phase, seedlings use the seed reserves, and if seedlings cannot elongate their roots, the reserves are directed to shoot development in the presence of aluminium, and to the activation of defence reactions.

Biochemical data are difficult to interpret, as they often follow a bell shaped curve, where the beginning (alarm) and the end stages of the stress (exhaustion) are very similar, and during the exposure to the stressful stimulus (resistance phase) biochemical parameters do not vary much (Kranner et al., 2010). Enzymes and proline, for example, are genotype responsive, and it is difficult to determine, based on enzyme and proline concentrations, if 
the stress experienced by plants is in the beginning or in the end stage. The same pattern was found by Moriya et al. (2015) in Phaseolus vulgaris submitted to natural and artificial ageing. In that study, only morphological characteristics were able to accurately discriminate lots subjected to different times of ageing (natural or artificial).

According to Bitencourt et al. (2011), Ramos et al. (2012), and Arroyave et al. (2011; 2013), the Basilisk cultivar is the most resistant to poor soils and to free aluminium. Based on the dendrogram made using the phenotypic characters for both assays, it could be seen that the Basilisk cultivar was the most distant cultivar in both dendrograms (Figure 7). The Marandu cultivar shares the same branch with the other cultivars, but in a position close to the Basilisk cultivar, meaning that it was more tolerant to aluminium, but not as aluminium tolerant as the Basilisk cultivar (Arroyave et al., 2011). Due to the seed effects, some alterations occurred and cultivars MG5, Piatã and Xaraés changed their places in the dendrogram. But when the germination influence was removed, Xaraés and MG5, which must be the same introduction (RNC, 2018) were very similar. However, the Marandu cultivar remained as the most tolerant after the Basilisk cultivar, while cultivars MG4 and Piatã have intermediate tolerance to aluminium.

Growth, measured as length and dry mass, can be understood as the positive sum of all reactions involved in the metabolism regarding defence against biotic and abiotic agents, net photosynthesis, and homeostasis, and the more positive the result, the better the growth. Any decrease in one of those variables may affect growth and, the bigger the influence, the smaller the growth. In some cases, this results in no growth, or even in the death of the living tissue. This means that growth measures must be able to reflect the impacts of any kind of stress in living organisms. Therefore, the use of germinated seedlings to determine tolerance/susceptibility to aluminium toxicity in controlled conditions, as well as measurement of root attributes such as length and dry weight, are appropriate tools for the discrimination of aluminium tolerant genotypes.

\section{Acknowledgements}

We would like to thank CAPES for the grant provided to C.J.T.Y, and we would like to thank CNPq for providing M.B.G. with a scholarship.

\section{References}

Ahmed, I. M., Nadira, U. A., Cao, F., He, X., Zhang, G., \& Wu, F. (2016). Physiological and molecular analysis on root growth associated with the tolerance to aluminum and drought individual and combined in Tibetan wild and cultivated barley. Planta, 243(4), 973-985. https://doi.org/10.1007/s00425-015-2442-X

Almeida, A. A. S., Monteiro, F. A., \& Jank, L. (2000). Avaliação de Panicum maximum Jacq. para tolerância ao alumínio em solução nutritiva. Revista Brasileira de Ciência do Solo, 24(2), 339-344. http://doi.org/10.1590/ S0100-06832000000200011

Ambiel, A. C., Machado, N., Guaberto, L. M., \& Vanderlei, T. M. (2010). Brachiaria germplasm dissimilarity as shown by RAPD markers. Crop Breeding and Applied Biotechnology, 10(1), 55-64. https://doi.org/10.12702/ 1984-7033.v10n01a08

Arroyave, C., Barceló, J., Poschenrieder, C., \& Tolrà, R. (2011). Aluminium-induced changes in root epidermal cell patterning, a distinctive feature of hyperresistance to Al in Brachiaria decumbens. Journal of Inorganic Biochemistry, 105(11), 1477-1483. https://doi.org/10.1016/j.jinorgbio.2011.07.011

Arroyave, C., Tolrà, R., Chaves, L., de Souza, M. C., Barceló, J., \& Poschenrieder, C. (2017). A proteomic approach to the mechanisms underlying activation of aluminium resistance in roots of Urochloa decumbens. Journal of Inorganic Biochemistry, 181, 145-151. https://doi.org/10.1016/j.jinorgbio.2017.09.010

Arroyave, C., Tolrà, R., Thuy, T., Barceló, J., \& Poschenrieder, C. (2013). Differential aluminum resistance in Brachiaria species. Environmental and Experimental Botany, 89, 11-18. https://doi.org/10.1016/j.envexpbot. 2013.01.001

Balbino, L. C., Cordeiro, L. A. M., Oliveira, P. D., Kluthcouski, J., Galerani, P. R., \& Vilela, L. (2012). Agricultura sustentável por meio da integração lavoura-pecuária-floresta (iLPF). Informações Agronômicas, 138, 1-18.

Bates, L. S., Waldren, R. P., \& Teare, I. D. (1973). Rapid determination of free proline for water-stress studies. Plant and Soil, 39(1), 205-207. https://doi.org/10.1007/BF00018060

Beefpoint. (2016). Retrieved from http://www.beefpoint.com.br/cadeia-produtiva/giro-do-boi/perfil-da-pecuariano-brasil-relatorio-anual-2016

Bitencourt, G. D. A., Chiari, L., Laura, V. A., Valle, C. B. D., Jank, L., \& Moro, J. R. (2011). Aluminum tolerance 
on genotypes of signal grass. Revista Brasileira de Zootecnia, 40(2), 245-250. https://doi.org/10.1590/ S1516-35982011000200003

Bradford, M. M. (1976). A rapid and sensitive method for the quantitation of microgram quantities of protein utilizing the principle of protein-dye binding. Analytical Biochemistry, 72(1-2), 248-254. https://doi.org/ 10.1016/0003-2697(76)90527-3

Brasil. (2009) Ministério da Agricultura e Reforma Agrária. Regras para análises de sementes. Brasília: SNDA/DNDV/CLAV.

Chen, Z. C., \& Liao, H. (2016). Organic acid anions: an effective defensive weapon for plants against aluminum toxicity and phosphorus deficiency in acidic soils. Journal of Genetics and Genomics, 43(11), 631-638. https://doi.org/10.1016/j.jgg.2016.11.003

Colombo, G. A., Melo, A. V., Machado Filho, G. C., \& Sousa, A. S. (2016). Semi-hydroponic cultivation as a selection tool for aluminum tolerance in forage grasses/cultivo semi-hidropônico como ferramenta de seleção para tolerância ao alumínio em gramíneas forrageiras. Revista Engenharia na Agricultura, 24(4), $350-356$. https://doi.org/10.13083/reveng.v24i4.654

Costa, N. R., Andreotti, M., Buzetti, S., Mascarenhas Lopes, K. S., Garcia dos Santos, F., \& Magalhães Pariz, C. (2014). Acúmulo de macronutrientes e decomposição da palhada de braquiárias em razão da adubação nitrogenada durante e após o consórcio com a cultura do milho. Revista Brasileira de Ciência do Solo, 38(4), 1223-1333. https://doi.org/10.1590/S0100-06832014000400019

Cruz, F. J. R., Silva Lobato, A. K., Costa, R. C. L., Santos Lopes, M. J., Neves, H. K. B., Oliveira Neto, C. F., ... Okumura, R. S. (2011). Aluminum negative impact on nitrate reductase activity, nitrogen compounds and morphological parameters in sorghum plants. Australian Journal of Crop Science, 5(6), 641-645. Retrieved from http://www.cropj.com/silva_5_6_2011_641_645.pdf

Cunha, G. O. D. M., Almeida, J. A. D., Testoni, S. A., \& Barboza, B. B. (2015). Forms of aluminum in Brazilian acid soils with exceptionally high levels of KCI-extractable $\mathrm{Al}^{3+}$. Revista Brasileira de Ciência do Solo, 39(5), 1362-1377. https://doi.org/10.1590/01000683rbcs20150017

Custódio, C. C., Bomfim, D. C., Saturnino, S. M., \& Machado Neto, N. B. (2002). Estresse por alumínio e por acidez em cultivares de soja. Scientia Agricola, 59(1), 145-153. https://doi.org/10.1590/S0103-90162002000 100021

Custódio, C. C., Salomão, G. R., \& Machado-Neto, N. B. (2009). Estresse hídrico na germinação e vigor de sementes de feijão submetidas a diferentes soluções osmóticas. Revista Ciência Agronômica, 40(4), 617-623. Retrieved from http://www.ccarevista.ufc.br/seer/index.php/ccarevista/article/viewFile/491/390

Delhaize, E., Craig, S., Beaton, C. D., Bennet, R. J., Jagadish, V. C., \& Randall, P. J. (1993). Aluminum tolerance in wheat (Triticum aestivum L.) (I. Uptake and distribution of aluminum in root apices). Plant Physiology, 103(3), 685-693. https://doi.org/10.1104/pp.103.3.685

Delhaize, E., Ryan, P. R., \& Randall, P. J. (1993). Aluminum tolerance in wheat (Triticum aestivum L.) (II. Aluminum-stimulated excretion of malic acid from root apices). Plant Physiology, 103(3), 695-702. https://doi.org/10.1104/pp.103.3.695

Echer, F. R., Custódio, C. C., Hosomi, S. T., Dominato, J. C., \& Machado-Neto, N. B. (2010). Estresse hídrico induzido por manitol em cultivares de algodão. Revista Ciência Agronômica, 41(4), 638-645. https://doi.org/ 10.1590/S1806-66902010000400018

EMBRAPA. (2014). Relatório de avaliação dos impactos das tecnologias geradas pela EMBRAPA Gado de Corte (p. 14). Campo Grande: Embrapa Gado de Corte.

Ferreira, D. F. (2008). SISVAR: Programa para análises e ensino de estatística. Revista Symposium, 6(2), 36-41.

Ferreira, S. (2016). Cenário do mercado de sementes de forrageira no Brasil. Anuário Abrasem 2016 (pp. 24-29). Retrieved from http://www.abrasem.com.br/wp-content/uploads,2013/09/Anaurio_ABRASEM_2016_ SITE.pdf

Flávio Neto, J., Severiano, E. D. C., Costa, K. A. D. P., Junnyor, W. S. G., Gonçalves, W. G., \& Andrade, R. (2015). Biological soil loosening by grasses from genus Brachiaria in crop-livestock integration. Acta Scientiarum. Agronomy, 37(3), 375-383. https://doi.org/10.4025/actasciagron.v37i3.19392

Giannakoula, A., Moustakas, M., Mylona, P., Papadakis, I., \& Yupsanis, T. (2008). Aluminum tolerance in maize is correlated with increased levels of mineral nutrients, carbohydrates and proline, and decreased levels of 
lipid peroxidation and Al accumulation. Journal of Plant Physiology, 165(4), 385-396. https://doi.org/ 10.1016/j.jplph.2007.01.014

Giannakoula, A., Moustakas, M., Syros, T., \& Yupsanis, T. (2010). Aluminum stress induces up-regulation of an efficient antioxidant system in the Al-tolerant maize line but not in the Al-sensitive line. Environmental and Experimental Botany, 67(3), 487-494. https://doi.org/10.1016/j.envexpbot.2009.07.010

Hare, P. D., \& Cress, W. A. (1997). Metabolic implications of stress-induced proline accumulation in plants. Plant Growth Regulation, 21(2), 79-102. https://doi.org/10.1023/A:1005703923347

Haussler, K., Rao, I. M., Schultze-Kraft, R., \& Marschner, H. (2006). Shoot and root growth of two tropical grasses, Brachiaria ruziziensis and $B$. dictyoneura, as influenced by aluminium toxicity and phosphorus deficiency in a sandy loam Oxisol of the eastern plains of Colombia. Tropical Grasslands, 40(4), 213-221. Retrieved from http://www.tropicalgrasslands.info/public/journals/4/Historic/Tropical\%20Grasslands\%20Journal\%20archiv e/PDFs/Vol_40_2006/Vol_40_04_2006_pp213_221.pdf

Heath, R. L., \& Packer, L. (1968). Photoperoxidation in isolated chloroplasts: I. Kinetics and stoichiometry of fatty acid peroxidation. Archives of Biochemistry and Biophysics, 125(1), 189-198. https://doi.org/10.1016/00039861(68)90654-1

Hossain, M. A., Ashrafuzzaman, M., \& Koyama, H. (2011). Reduction of Al-induced oxidative damage in wheat. Australian Journal of Crop Science, 5(10), 1157-1162. Retrieved from http://www.cropj.com/ashrafuzzaman _5_10_2011_1157_1162.pdf

Hunt, R. (1982). Plant growth curves: The functional approach to plant growth analysis (p. 248). Edward Arnold, London.

IBGE (Instituto Brasileiro de Geografia e Estatística). (2006). Censo da Agropecuária IBGE. Rio de Janeiro, RJ, Brasil.

Karia, C. T., Duarte, J. B., \& Araújo, A. D. (2006). Desenvolvimento de cultivares do gênero Brachiaria (Trin.) Griseb. no Brasil. Planaltina: Embrapa Cerrados. Retrieved from https://ainfo.cnptia.embrapa.br/digital/ bitstream/CPAC-2009/27809/1/doc_163.pdf

Kikui, S., Sasaki, T., Maekawa, M., Miyao, A., Hirochika, H., Matsumoto, H., \& Yamamoto, Y. (2005). Physiological and genetic analyses of aluminium tolerance in rice, focusing on root growth during germination. Journal of Inorganic Biochemistry, 99(9), 1837-1844. https://doi.org/10.1016/j.jinorgbio. 2005.06.031

Kranner, I., Minibayeva, F. V., Beckett, R. P., \& Seal, C. E. (2010). What is stress? Concepts, definitions and applications in seed science. New Phytologist, 188(3), 655-673. https://doi.org/10.1111/j.1469-8137.2010. 03461.x

Liu, J., Piñeros, M. A., \& Kochian, L. V. (2014). The role of aluminum sensing and signaling in plant aluminum resistance. Journal of Integrative Plant Biology, 56(3), 221-230. https://doi.org/10.1111/jipb.12162

Ma, J. F., Chen, Z. C., \& Shen, R. F. (2014). Molecular mechanisms of Al tolerance in gramineous plants. Plant and Soil, 381(1-2), 1-12. https://doi.org/10.1007/s11104-014-2073-1

Ma, J. F., Ryan, P. R., \& Delhaize, E. (2001). Aluminium tolerance in plants and the complexing role of organic acids. Trends in Plant Science, 6(6), 273-278. https://doi.org/10.1016/S1360-1385(01)01961-6

Machado Neto, N. B., Saturnino, S. M., Bomfim, D. C., \& Custódio, C. C. (2004). Water stress induced by mannitol and sodium chloride in soybean cultivars. Brazilian Archives of Biology and Technology, 47(4), 521-529. https://doi.org/10.1590/S1516-89132004000400004

Machado, P. L. O. A. (1997). Considerações gerais sobre a toxicidade do alumínio nas plantas (p. 22). Rio de Janeiro: EMBRAPA/CNPS.

Martins, C. E., Souza Sobrinho, F. D., Gomes, F. T., Rocha, W. S. D. D., \& Brighenti, A. M. (2010). Tolerância à toxidez por alumínio em capim-elefante. Revista Brasileira de Tecnologia Aplicada nas Ciências Agrárias, 3(1), 21-28. Retrieved from https://revistas.unicentro.br/index.php/repaa/article/viewFile/655/1051

Matins, C. E., Miguel, P. S. B., Rocha, W. S. D. D., Sobrinho, F. S., Gomes, F. T., \& Oliveira, A. V. D. (2011). Seleção de genótipos de Brachiaria ruziziensis quanto à tolerância ao alumínio em solução nutritiva: I: Resposta a diferentes concentrações de alumínio e valores de ph em solução nutritiva. Revista de Ciências Agrárias, 34(1), 154-162. Retrieved from http://www.scielo.mec.pt/pdf/rca/v34n1/v34n1a14.pdf 
Miguel, P. S. B., Rocha, W. S. D. D., Sobrinho, F. S., Martins, C. E., Gomes, F. T., Oliveira, A. V. D., \& Carvalho, C. A. D. (2011). Seleção de genótipos de Brachiaria ruziziensis quanto ao alumínio em solução nutritiva: II: Avaliação da tolerância ao alumínio. Revista de Ciências Agrárias, 34(1), 163-172. Retrieved from http://www.scielo.mec.pt/pdf/rca/v34n1/v34n1a15.pdf

Miles, J. W., Maass, B. L., \& Valle, C. B. D. (1996). Brachiaria: Biology, Agronomy and Improvement (1st ed.). Cali, Colombia: CIAT.

Moriya, L. M., Machado-Neto, N. B., Marks, T. R., \& Custódio, C. C. (2015). Seed vigour better to be assessed by physiological markers rather than expression of antioxidant enzymes in the common bean (Phaseolus vulgaris L.). Australian Journal of Crop Science, 9(1), 30-40. Retrieved from http://www.cropj.com/ machado_9_1_2015_30_40.pdf

Mutimura, M., \& Everson, T. M. (2012). On-farm evaluation of improved Brachiaria grasses in low rainfall and aluminium toxicity prone areas of Rwanda. International journal of Biodiversity and Conservation, 4(3), 137-154. https://doi.org/10.5897/IJBC10.121

Nakagawa, J. (1999). Testes de vigor baseados nos desempenhos das plântulas. In F. C. Krzyzanowski, R. D. Vieira, \& J. D. B. França Neto (Eds.), Vigor de sementes: Conceitos e testes (pp. 2-24). Londrina: ABRATES.

Nolla, A., Schlindwein, J. A., \& Anghinoni, I. (2007). Crescimento, morfologia radicular e liberação de compostos orgânicos por plântulas de soja em função da atividade de alumínio na solução do solo de campo natural. Ciência Rural, 37(1), 97-101. https://doi.org/10.1590/S0103-84782007000100016

Oliveira Silva, R., Barioni, L. G., Hall, J. A. J., Matsuura, M. F., Albertini, T. Z., Fernandes, F. A., \& Moran, D. (2016). Increasing beef production could lower greenhouse gas emissions in Brazil if decoupled from deforestation. Nature Climate Change, 6(5), 493. http://doi.org/10.1038/NCLIMATE2916

Raij, B. V., Cantarella, H., Quaggio, J. A., Furlani, A. M. C. (1997). Recomendações de adubação e calagem para o estado de São Paulo (Boletim Técnico, 100, p. 285). Campinas: Instituto Agronômico/Fundação IAC.

Ramos, F. T., França, M. G., Alvim, M. N., Rossiello, R. O., \& Zonta, E. (2012). Aluminum tolerance measured by root growth and mucilage protection in Urochloa brizantha and Urochloa decumbens. Journal of Plant Interactions, 7(3), 225-229. https://doi.org/10.1080/17429145.2012.693207

Rao, I. M., Miles, J. W., Beebe, S. E., \& Horst, W. J. (2016). Root adaptations to soils with low fertility and aluminium toxicity. Annals of Botany, 118(4), 593-605. https://doi.org/10.1093/aob/mcw073

Rao, I. M., Miles, J. W., García, R., \& Ricaurte Oyola, J. J. (2006). Selección de híbridos de Brachiaria con resistencia al aluminio. Pasturas Tropicales, 28(1), 20-25. Retrieved from http://tropicalgrasslands.info/ public/journals/4/Elements/DOCUMENTS/2006-vol28-rev1-2-3/Vol_28_rev1_06_pags_20-25.pdf

Re, R., Pellegrini, N., Proteggente, A., Pannala, A., Yang, M., \& Rice-Evans, C. (1999). Antioxidant activity applying an improved ABTS radical cation decolorization assay. Free Radical Biology and Medicine, 26(9-10), 1231-1237. https://doi.org/10.1016/S0891-5849(98)00315-3

RNC (Registro Nacional de Cultivares). (2018). Ministério da Agricultura, Pecuária e Abastecimento. Retrieved from http://www.agricultura.gov.br/guia-de-servicos/registro-nacional-de-cultivares-rnc

Rosado, R. D. S., Sessa Fialho, G., Souto Dias, B. A., Barbosa Rosado, T., Prieto Martinez, H. E., \& Galvêas Laviola, B. (2012). Screening Jatropha genotypes for aluminum tolerance using the solution-paper method. Semina: Ciências Agrárias, 33(4), 1273-1280. https://doi.org/10.5433/1679-0359.2012v33n4p1273

Roselló, M., Poschenrieder, C., Gunsé, B., Barceló, J., \& Llugany, M. (2015). Differential activation of genes related to aluminium tolerance in two contrasting rice cultivars. Journal of Inorganic Biochemistry, 152, 160-166. https://doi.org/10.1016/j.jinorgbio.2015.08.021

Sano, E. E., Rosa, R., Brito, J. L. S., \& Ferreira, L. G. (2008). Semidetailed land use mapping in the Cerrado. Pesquisa Agropecuária Brasileira, 43(1), 153-156. https://doi.org/10.1590/S0100-204X2008000100020

Silva, S. (2012). Aluminium toxicity targets in plants. Journal of Botany, 2012(219462), 8. https://doi.org/ $10.1155 / 2012 / 219462$

Silva, S., Pinto, G., Correia, B., Pinto-Carnide, O., \& Santos, C. (2013). Rye oxidative stress under long term Al exposure. Journal of Plant Physiology, 170(10), 879-889. https://doi.org/10.1016/j.jplph.2013.01.015

Tamas, L., Budikova, S., Simonovicova, M., Huttova, J., Siroka, B., \& Mistrik, I. (2006). Rapid and simple method for Al-toxicity analysis in emerging barley roots during germination. Biologia Plantarum, 50(1), 87-93. 
https://doi.org/10.1007/s10535-005-0079-5

Too, E. J., Were, B. A. I., Onkware, A. O., Ringo, J. H., Carlsson, A. S., Ouma, E., ... Gudu, S. (2014). Response of selected sorghum (Sorghum bicolor L. Moench) germplasm to aluminium stress. African Journal of Agricultural Research, 9(21), 1651-1662. http://doi.org/10.5897/AJAR2013.7795

USDA. (2018). Livestock and Poultry: World Markets and Trade. Retrieved from https://apps.fas.usda.gov/ psdonline/circulars/livestock_poultry.pdf

Wenzl, P., Patino, G. M., Chaves, A. L., Mayer, J. E., \& Rao, I. M. (2001). The high level of aluminum resistance in signalgrass is not associated with known mechanisms of external aluminum detoxification in root apices. Plant Physiology, 125(3), 1473-1484. https://doi.org/10.1104/pp.125.3.1473

Zaifnejad, M., Clark, R. B., \& Sullivan, C. Y. (1997). Aluminum and water stress effects on growth and proline of sorghum. Journal of Plant Physiology, 150(3), 338-344. https://doi.org/10.1016/S0176-1617(97)80130-7

\section{Copyrights}

Copyright for this article is retained by the author(s), with first publication rights granted to the journal.

This is an open-access article distributed under the terms and conditions of the Creative Commons Attribution license (http://creativecommons.org/licenses/by/4.0/). 